\title{
К вопросу о классификации факторов формирования инновационной восприимчивости региона
}

\author{
Владимирова О.Н. ${ }^{14}$, Дягель О.Ю. $^{15}$
}

В статье проведена систематизачия и классификация факторов инновационной восприимчивости региона с использованием структуры признаков, имеющих разнье свойства (степень влияния, характер и уровень воздействия, структуру инновачионной деятельности и др.). Это позволяет определить возможные направления оказания управленческого воздействия на готовность региона к осуществлению инноваций.

JEL: 0310

Ключевые слова: регион, инновационная восприимчивость, факторы, признаки классификации

Факторы развития экономических систем в различное время исследовались классиками экономического анализа, а позднее были уточнены и дополнены современными ученымиэкономистами. Инновационный характер, присущий современному этапу развития систем, определяет необходимость идентификации факторов инновационной восприимчивости, что является предметом настоящей публикации.

Поясним, что под инновационной восприимчивостью авторы понимают наличие и способность субъектов региона и органов исполнительной власти создавать, осуществлять и реализовывать инновационные процессы, исходя из имеющихся условий и ресурсов, в рамках определенной и проводимой региональной инновационной политики. Инновационная восприимчивость является важнейшей характеристикой, отражающей готовность региона к осуществлению инноваций, а ее формирование определяется рядом факторов и условий развития современной экономики (Владимирова, 2011).

Опираясь на результаты анализа научных трудов и накопленного опыта инновационной деятельности, под факторами будем понимать условия и предпосылки, которые на основе взаимодействия способствуют изменению существующего порядка во временной и пространственной плоскостях и определяют объективные возможности трансформации сложившегося порядка (Беляев, Максимчук, 2006).

Таким образом, рассматривая факторы как существенные обстоятельства, влияющие на экономический процесс, и опираясь на приведенное выше понимание инновационной восприимчивости, авторами статьи было проведено обобщение факторов, ее определяющих. Также осуществлена их систематизация (таблица 1) как по группам значимости, так и по определенным уровням, среди которых: регион, предприятие, организации финансовокредитной сферы, организации научной сферы, организации образовательной сферы, общественные организации, гражданское общество. Приведенные факторы отражают специфику каждого уровня, заключающуюся в том, что каждый из них имеет свою ресурсную базу, экономические интересы, сферы влияния. Факторы были распределены по следующим группам: инновационная активность, техническая и технологическая обеспеченность, человеческий фактор, финансово-кредитное и инвестиционное, структурное и инфраструктурное, нормативно-правовое обеспечение.

Инновационная восприимчивость региона формируется как совокупность

\footnotetext{
14 Канд. эконом. наук, профессор кафедры «Финансы и кредит» Красноярского государственного торговоэкономического института.

${ }^{15}$ Канд. эконом. наук, доцент кафедры «Экономический анализ и статистика» Красноярского государственного торгово-экономического института.
} 
восприимчивости субъектов, функционирующих на его территории, и одновременно зависит от ряда особенностей, обуславливаемых спецификой региона как сложной системы.

Таблица 1

Матрица факторов инновационной восприимчивости

\begin{tabular}{|c|c|c|c|c|c|c|}
\hline Факторы & $\begin{array}{c}\text { Инновационная } \\
\text { активность } \\
\text { субъектов }\end{array}$ & $\begin{array}{c}\text { Техническая и } \\
\text { технологическая } \\
\text { обеспеченность }\end{array}$ & $\begin{array}{c}\text { Человеческий и } \\
\text { кадровый фактор }\end{array}$ & $\begin{array}{c}\text { Финансово- } \\
\text { кредитное и } \\
\text { инвестиционное } \\
\text { обеспечение } \\
\end{array}$ & $\begin{array}{c}\text { Инфраструктурно } \\
\text { е обеспечение }\end{array}$ & $\begin{array}{l}\text { Нормативно- } \\
\text { правовое } \\
\text { обеспечение }\end{array}$ \\
\hline Регион & $\begin{array}{l}\text { - наличие условий } \\
\text { для } \\
\text { инновационной } \\
\text { деятельности; } \\
\text { - наличие крупных } \\
\text { бизнес-структур; } \\
\text { - потенциал и опыт } \\
\text { малых и средних } \\
\text { предприятий; } \\
\text { - эффективная } \\
\text { координация } \\
\text { государственных } \\
\text { действий; } \\
\end{array}$ & $\begin{array}{l}\text {-несбалансирован- } \\
\text { ность структуры } \\
\text { технологического } \\
\text { капитала; } \\
\text { - неэффективность } \\
\text { использования } \\
\text { технологического } \\
\text { капитала }\end{array}$ & $\begin{array}{l}\text { - демографическая } \\
\text { ситуация; } \\
\text { - безработица; } \\
\text { - уровень доходов } \\
\text { - социальные } \\
\text { условия; } \\
\text { - структурный (по } \\
\text { профессиям) и } \\
\text { абсолютный } \\
\text { дефицит кадров; } \\
\text { - мобильность } \\
\text { кадров }\end{array}$ & \begin{tabular}{|l|} 
- достаточность \\
средств \\
регионального \\
бюджета; \\
- наличие \\
внебюджетных \\
источников; \\
- софинансирование \\
из федерального \\
бюджета; \\
- целевое \\
финансирование
\end{tabular} & $\begin{array}{l}\text { - наличие отраслей } \\
\text { приоритетных } \\
\text { направлений; } \\
\text { - } \\
\text { институциональная } \\
\text { структура; } \\
\text {-наличие } \\
\text { инновационной } \\
\text { инфраструктуры }\end{array}$ & $\begin{array}{l}\text { - } \quad \text { региональное } \\
\text { инновационное } \\
\text { законодательство; } \\
\text { - } \quad \text { региональная } \\
\text { инновационная, } \\
\text { научно- } \\
\text { техническая, } \\
\text { промышленная } \\
\text { политика }\end{array}$ \\
\hline $\begin{array}{l}\text { Предприя } \\
\text { тие }\end{array}$ & \begin{tabular}{|lr} 
- экономическая \\
мотивация \\
инновационной \\
деятельности; \\
- спрос на \\
инновационную \\
продукцию;
\end{tabular} & $\begin{array}{l}\text { - износ основных } \\
\text { фондов; } \\
-\quad \text { наличие } \\
\text { доступность } \\
\text { современного } \\
\text { оборудования } \\
\text { отечественного } \\
\text { производства }\end{array}$ & $\begin{array}{l}\text { - наличие } \\
\text { работников } \\
\text { необходимых } \\
\text { специальностей и } \\
\text { квалификации; } \\
\text { - способность } \\
\text { кадров } \\
\text { восприятию } \\
\text { инноваций; } \\
\text { - деформированная } \\
\text { возрастная } \\
\text { структура; } \\
\text { - } \\
\text { внутрифирменная } \\
\text { подготовка кадров } \\
\end{array}$ & $\begin{array}{l}\text { - наличие источников } \\
\text { финансирования; } \\
-\quad \text { наличие } \\
\text { доступность } \\
\text { инструментов } \\
\text { финансирования; } \\
\text { - стоимость } \\
\text { финансовых } \\
\text { ресурсов; дисбаланс } \\
\text { - струкуры } \\
\text { инвестиций; } \\
\text {-снижение } \\
\text { финансовой } \\
\text { устойчивости } \\
\end{array}$ & $\begin{array}{l}-\quad \text { наличие } \\
\text { внутренних } \\
\text { подразделений } \\
\text { НИОКР в структуре } \\
\text { предприятия; } \\
\text { - научно- } \\
\text { техническая } \\
\text { кооперация; } \\
\text { - обращение к } \\
\text { внешним } \\
\text { источникам } \\
\text { информации }\end{array}$ & $\begin{array}{l}\text { - государственное } \\
\text { инновационное } \\
\text { законодательство } \\
-\quad \text { региональная } \\
\text { инновационная, } \\
\text { научно- } \\
\text { техническая, } \\
\text { промышленная } \\
\text { политика }\end{array}$ \\
\hline 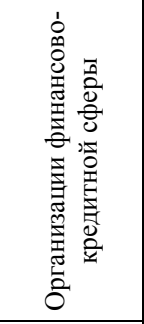 & \begin{tabular}{|lr} 
- & слабая \\
корреляция & \\
зависимости & \\
конечных & \\
результатов & от \\
содействия & \\
инновационной & \\
деятельности &
\end{tabular} & $\begin{array}{lr}- & \text { отсутствие } \\
\text { заинтересованност } \\
\text { и; } \\
-\quad \text { централизация } \\
\text { регулирования }\end{array}$ & $\begin{array}{l}\text { - высокий уровень } \\
\text { заработной платы }\end{array}$ & \begin{tabular}{|l} 
- высокий уровень \\
риска; \\
- длительный период \\
вложений; \\
- угроза стабильности \\
финансового рынка
\end{tabular} & \begin{tabular}{|l} 
- реформирование \\
банковского \\
сектора; наличие \\
- рыночных \\
институтов \\
(институты \\
развития, \\
венчурные фонды и \\
др.) \\
\end{tabular} & $\begin{array}{l}-\quad \text { регулирование } \\
\text { уполномоченным } \\
\text { органом - ЦБ РФ; } \\
-\quad \text { особый } \\
\text { механизм участия } \\
\text { в инновационной } \\
\text { деятельности }\end{array}$ \\
\hline 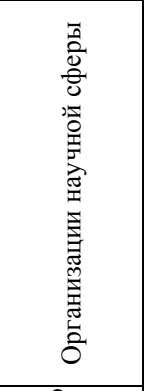 & \begin{tabular}{|l|} 
- слабая \\
корреляция \\
зависимости \\
конечных \\
результатов \\
экономических \\
стимулов;
\end{tabular} & \begin{tabular}{|lc} 
- & устаревшее \\
оборудование; \\
- возможность \\
приобретения; \\
- доступ к \\
уникальному и \\
дорогостоящему \\
оборудованию;
\end{tabular} & $\begin{array}{l}\text { - численность } \\
\text { исследователей; } \\
\text { - квалификация; } \\
\text {-миграция и } \\
\text { молодых квалифицированн } \\
\text { квах ученых; } \\
\text { ых учевень } \\
\text { - низкий уровень } \\
\text { заработной платы; } \\
\text { - деформированная } \\
\text { возрастная } \\
\text { структура; } \\
\end{array}$ & \begin{tabular}{|l|} 
- высокая стоимость \\
оборудования; \\
- наличие источников \\
и достаточность \\
финансовых \\
ресурсов; \\
- дисбаланс \\
структуры \\
финансирования; \\
- финансовые формы \\
поддержки;
\end{tabular} & $\begin{array}{l}\text { - новые формы } \\
\text { интегрированного } \\
\text { использования } \\
\text { дорогостоящего } \\
\text { оборудования } \\
\text { (центры } \\
\text { коллективного } \\
\text { пользования и др.) }\end{array}$ & $\begin{array}{l}\text { - установление } \\
\text { особого статуса } \\
\text { научных } \\
\text { организаций } \\
\text { (государственные } \\
\text { академии, } \\
\text { наукограды и } \\
\text { др.); } \\
\text { - актуализация } \\
\text { образовательных } \\
\text { программ; }\end{array}$ \\
\hline 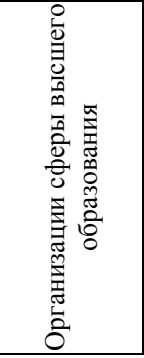 & $\begin{array}{l}\text { - низкая доля } \\
\text { научных } \\
\text { разработок; } \\
\text { - ограничения } \\
\text { экономического } \\
\text { стимулирования }\end{array}$ & $\begin{array}{l}\text { - моральное } \\
\text { устаревание } \\
\text { учебного } \\
\text { оборудования; } \\
\text { - наличие } \\
\text { современных } \\
\text { методов } \\
\text { технологий } \\
\text { обучения }\end{array}$ & $\begin{array}{l}\text { - возрастная } \\
\text { структура } \\
\text { профессорско- } \\
\text { преподавательског } \\
\text { о состава; } \\
\text { - наличие } \\
\text { конкурентоспособ } \\
\text { ных } \\
\text { преподавателей, } \\
\text { исследователей и } \\
\text { управленцев }\end{array}$ & \begin{tabular}{|lr|} 
- & ограниченные \\
финансовые ресурсы; & \multicolumn{2}{c}{ структурный } \\
- & дисбаланс \\
источников; & \multicolumn{1}{c}{ ограничение } \\
$-\quad$ применения \\
рыночных \\
инструментов \\
финансирования
\end{tabular} & $\begin{array}{l}\text { - новые формы } \\
\text { интегрированного } \\
\text { использования } \\
\text { дорогостоящего } \\
\text { оборудования } \\
\text { (центры } \\
\text { коллективного } \\
\text { пользования и др.) }\end{array}$ & $\begin{array}{l}\text { - законодательная } \\
\text { основа создания } \\
\text { малых } \\
\text { инновационных } \\
\text { предприятий при } \\
\text { высших учебных } \\
\text { заведениях }\end{array}$ \\
\hline
\end{tabular}




\begin{tabular}{|c|c|c|c|c|c|c|}
\hline Факторы & $\begin{array}{c}\text { Инновационная } \\
\text { активность } \\
\text { субъектов }\end{array}$ & $\begin{array}{c}\text { Техническая и } \\
\text { технологическая } \\
\text { обеспеченность }\end{array}$ & $\begin{array}{c}\text { Человеческий и } \\
\text { кадровый фактор }\end{array}$ & $\begin{array}{c}\text { Финансово- } \\
\text { кредитное и } \\
\text { инвестиционное } \\
\text { обеспечение }\end{array}$ & $\begin{array}{c}\text { Инфраструктурно } \\
\text { е обеспечение }\end{array}$ & $\begin{array}{l}\text { Нормативно- } \\
\text { правовое } \\
\text { обеспечение }\end{array}$ \\
\hline 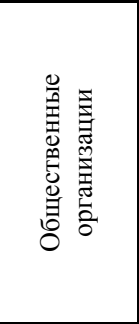 & $\begin{array}{l}\text { - поддержка } \\
\text { инновационных } \\
\text { инициатив }\end{array}$ & $\begin{array}{l}\text { - содействие } \\
\text { созданию } \\
\text { благоприятных } \\
\text { условий для } \\
\text { инновационных } \\
\text { процессов }\end{array}$ & $\begin{array}{l}\text { - формирование и } \\
\text { поддержка } \\
\text { престижа и } \\
\text { признания имиджа } \\
\text { инноватора; } \\
\text { - формирование } \\
\text { культуры } \\
\text { инноваций } \\
\text { обществе }\end{array}$ & $\begin{array}{|lr|}\text { - } \quad \text { распространение } \\
\text { передового } \\
\text { отечественного опыта } \\
\text { предпринимательства }\end{array}$ & $\begin{array}{l}\text { - многообразие } \\
\text { форм } \\
\text { общественных } \\
\text { организаций; } \\
\text { - оказание } \\
\text { практической } \\
\text { помощи научно- } \\
\text { техническим и } \\
\text { инновационным } \\
\text { организациям; }\end{array}$ & $\begin{array}{l}\text { - содействие } \\
\text { совершенствова- } \\
\text { нию } \\
\text { законодательства } \\
\text { в } \quad \text { интересах } \\
\text { поддержки } \\
\text { отечественного } \\
\text { производителя } \\
\text { товаров и услуг; }\end{array}$ \\
\hline 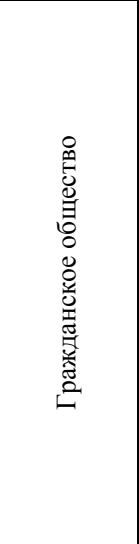 & \begin{tabular}{|lc}
\multicolumn{1}{c}{ мотивация } & к \\
инновационной & \\
деятельности &
\end{tabular} & $\begin{array}{l}\text { - способность и } \\
\text { наличие } \\
\text { квалификации } \\
\text { применять } \\
\text { современные } \\
\text { технологии }\end{array}$ & $\begin{array}{ll}\text { - способность и } \\
\text { готовность } \\
\text { непрерывному } \\
\text { образованию, } \\
\text { переобучению и } \\
\text { самообучению, } \\
\text { профессиональной } \\
\text { мобильности; } \\
\text {-способность } \\
\text { критическому } \\
\text { мышлению; } \\
\text {-креативность и } \\
\text { предприимчивость } \\
\text { готовность к } \\
\text { работе } \\
\text { высококонкурентн } \\
\text { ой среде }\end{array}$ & $\begin{array}{l}\text { - уровень } \\
\text { благосостояния; } \\
\text { - наличие и доступ к } \\
\text { финансовым } \\
\text { ресурсам }\end{array}$ & $\begin{array}{l}-\quad \text { обеспеченность } \\
\text { институтами; } \\
\text { - уровень } \\
\text { взаимодействия с } \\
\text { институтами }\end{array}$ & \begin{tabular}{|l}
$-\quad$ наличие \\
инновационного \\
законодательства
\end{tabular} \\
\hline
\end{tabular}

Рассмотрим содержание и характеристику влияния факторов более подробно.

1. Императивом перехода экономики на инновационный путь развития является инновационная активность субъектов. К настоящему времени доля компаний-инноваторов в России примерно в три раза ниже, чем в развитых странах. Исследования показали, что уровень инновационной активности во многом зависит от характеристик самих компаний: более высокая интенсивность активности свойственна крупным частным компаниям, более низкая - государственным или с частичным государственным участием. Преимущества крупного бизнеса в осуществлении инноваций во многом обуславливаются отсутствием развитых рынков капитала, человеческого капитала и продукции, наличием политических связей. В международной практике в странах догоняющего развития крупные компании являются лидерами инновационного развития, в странах-передовиках инновации в основном осуществляются в малом бизнесе (Acemoglu et al., 2006; Acemoglu et al., 2007).

Данные недавних опросов в Российской Федерации свидетельствуют о том, что инновационная активность промышленных предприятий, особенно средних (численностью до 250 человек) снизилась. Как показал опрос 1000 крупных и средних предприятий восьми отраслей промышленности, проведенный в 2009 году, только 3\% предприятий, попавших в выборку, ориентируются на уровень мирового рынка; в большинстве среднетехнологичных отраслей инновации были новыми только для внутреннего российского рынка, а в низкотехнологичных преобладают имитаторы. Соответственно, сократилось и число предприятий, финансирующих НИОКР, с 54,8\% в 2005 году до 36\% в 2009 году. Такой результат только отчасти можно объяснить влиянием кризиса. Главной проблемой является неблагоприятный инновационный климат в стране (Гончар, 2009).

Национальной ассоциацией инноваций и развития информационных технологий (НАИРИТ) в 2009 году был составлен «Рейтинг инновационной активности регионов 2009», по результатам которого все регионы России были разделены на пять групп:

1) лидеры инновационной активности (Москва и Санкт-Петербург);

2) высокая инновационная активность (14 регионов, в числе которых три региона Сибирского федерального округа - Томская и Новосибирская области, Алтайский край);

3) средняя инновационная активность (24 региона, в том числе Красноярский край); 
4) низкая инновационная активность (28 регионов, в том числе Кемеровская область, Республика Алтай, Забайкальский край);

5) отстающие (14 регионов, в том числе Иркутская область, Республика Хакасия и Республика Тыва) (НАИРИТ составила... 2009).

Таким образом, 2,3\% регионов являются лидерами, $16,6 \%$ имеют высокую инновационную активность и $50 \%$ относятся к группам с низкой инновационной активностью и отстающим.

Существенное влияние на формирование инновационной восприимчивости региона оказывает техническое и технологическое обеспечение. Технологическое отставание России от передовых стран за последние годы усиливается. По оценкам, мировому уровню соответствует лишь четвертая часть применяемых в промышленности технологий. В большинстве случаев на промышленных предприятиях применяются технологии 1960-1970х годов. Средний возраст станочного оборудования превышает 30 лет. По структуре и прежде всего по наличию обрабатывающих центров с ЧПУ, доля которых в парке эксплуатируемого оборудования не превышает 5\%, состав оборудования соответствует техническому уровню середины 1980-х годов. Для сравнения: за рубежом количество используемого высокотехнологичного оборудования с ЧПУ приближается к $50 \%$, а для предприятий, производящих технологическую оснастку (пресс-формы, штампы, литейные формы и др.) достигает 85\% (Митяшин, 2010).

Анализ информации из других источников показывает, что в целом для России и для регионов в частности техническое и технологическое обеспечение характеризуется:

2. Несбалансированностью технологического капитала. Крайняя физическая изношенность оборудования, значительная доля иностранного оборудования, низкие показатели внедрения новых технологий и загрузки производственных площадей, разрывы между отдельными отраслями сосуществуют с высокими показателями применения информационно-коммуникационных технологий. В целом по России (а в отдельных регионах ситуация характеризуется более негативно) в 2009 году средний уровень износа основных средств составляет более 60\%. При этом сохраняются барьеры для распространения новых технологий, обусловленные отраслевым регулированием, процедурами сертификации, устаревшими регламентами и стандартами.

3. Неэффективным использованием составляющих технологического капитала. Достижение технического предела в традиционных отраслях не оправдывает инновационные риски, связанные с проведением оригинальных НИОКР. По данным Минэкономразвития, восприимчивость бизнеса к инновациям технологического характера остается низкой, в 2009 году разработку и внедрение технологических инноваций осуществляли 9,4\% от общего числа предприятий отечественной промышленности, что значительно ниже значений, характерных для Германии (69,7\%), Ирландии (56.7\%), Бельгии $(59,6 \%)$, Эстонии $(55,1 \%)$, Чехии (36,6\%). Мала доля предприятий, инвестирующих в приобретение новых технологий $(11,8 \%)$. Низка не только доля инновационно активных предприятий, но и интенсивность затрат на технологические инновации, составляющая в России 1,9\% (аналогичный показатель в Швеции - 5,5\%, в Германии - 4,7\%). Для инновационного спроса характерна его неэффективная структура: избыточный перекос в сторону закупки готового оборудования за рубежом в ущерб внедрению собственных новых разработок (Инновационная Россия...).

Инновационное развитие предполагает и основывается на новой роли человека. Одновременно определяя человеческий и кадровый капитал в качестве одного из важнейших факторов формирования инновационной восприимчивости, следует учитывать негативные тенденции, выражающиеся в совокупности ниже следующих тенденций.

1. Структурный (по профессиям) и абсолютный дефицит кадров. Структурный дефицит обусловлен: преобладанием в подготовке специалистов нетехнических направлений; отсутствием стимулов материальной поддержки выпускников, что в свою очередь, как следствие, определяет отток перспективной молодежи за рубеж и достаточно высокий 
возрастной уровень профессионалов.

В 2005-2010 годы в России наблюдается падение уровня рождаемости (во многом это определялось социально-экономическими условиями, подменой морально-этических норм в обществе), рост смертности (особенно высокая смертность мужчин в трудоспособном возрасте), повышение удельного веса категории пенсионного возраста в общей совокупности населения.

К концу 1980-х число людей пенсионного возраста превысило 1/5 часть от всего населения; при этом отношение числа пенсионеров к числу граждан в трудоспособном возрасте возросло до 1:3. В сравнении с другими странам соотношение численности возрастных групп 15-64 года и старше 65 лет в России составляет 33,7\%, тогда как для Бразилии - 7,7\%, Южной Кореи - 9,8\%, Китая - 10\%, США - 18\%, Германии - 24,1\%, Великобритании - 24,2\% (Рубанов, 2009). Это ведет к уменьшению общей численности доли экономически активного населения и, соответственно, к сокращению потенциала данного ресурса. По статистическим данным, за последние восемь лет население России сократилось на 2 млн человек, при этом только за 2010 год - на 50 тыс. человек.

2. Недостаточное количество высококвалифицированных кадров. Данный аспект объединяет несколько компонентов: преобладание в подготовке специалистов нетехнических направлений; отсутствие стимулов материальной поддержки выпускников, что в свою очередь, как следствие, определяет отток перспективной молодежи за рубеж и достаточно высокий возрастной уровень профессионалов. В 2008 году удельный вес возрастных групп до 29 лет и 30-39 лет, по мнению исследователей, составил 17,6 и 14,2\% соответственно, при одновременном увеличении за восемь лет доли исследователей в возрасте 60 лет и старше с 20, до 25,2\% (Инновационная Россия...).

Низкий уровень инновационного развития в России способствует «утечке мозгов» на Запад. Об этом сообщается в материалах Национальной ассоциации инноваций и развития информационных технологий (НАИРИТ). Только за 2009 год из России уехали около 6100 научных специалистов. Эти данные позволяют говорить об очередной активизации процесса «утечки мозгов». Последний раз такое количество ученых покидало страну в 2006 году, когда еще не действовала государственная программа поддержки инновационного развития. В ассоциации полагают, что столь низкая эффективность инновационного развития объясняется некомпетентностью и непрозрачностью работы государственных чиновников, отвечающих за ход федеральных инновационных программ и проектов (Российские «мозги»...).

Особо остро это проявляется в научно-исследовательской сфере: по числу исследователей на 1000 занятых в экономике Россия уступает более чем двадцати государствам, в том числе Финляндии, Франции, Германии, США Японии и др.

Для России характерна концентрация высококвалифицированных специалистов в ограниченном числе регионов, что снижает потенциал других регионов. Основными центрами науки в Российской Федерации (по показателю численности исследователей) в 2009 были: Москва (239 477 чел.), Санкт-Петербург (81 430 чел.), Нижегородская область (40 909 чел.), Новосибирская область (21 622 чел.), Свердловская область (20 390 чел.). При этом в Ленинградской области данный показатель составляет 6463 чел., в Томской области - 8560 чел., Красноярском крае - 6299 чел. (Регионы России, 2010). Таким образом, четко выявляется неравномерное распределение исследователей по регионам страны.

3. Состояние образовательной сферы. Хроническое недофинансирование сферы образования (Россия расходовала на образование в 2007 году 4,0\% ВВП, тогда как Финляндия - 5,9\%, США - 5,3\%, Франция - 5,6\%, Бразилия - 5,2\%, Южная Корея - 4,2\%), структурные проблемы, включая устаревшие модели управления учебным процессом, нехватку в системе образования современных кадров, в том числе управленческих, определяют современное состояние образовательной сферы. За последние годы, по данным Минэкономразвития, реализована финансовая поддержка инновационных программ 57 вузов (в 2005-2008 годах на эти цели было выделено 30 млрд рублей). 
По подсчетам специалистов, в развитых странах коэффициент выбытия основного капитала составляет 4-4,5\%, а в наиболее быстро развивающихся отраслях хозяйства - 7-9\%. Это означает, что знания специалистов в соответствующих областях устаревают за 7-10 лет, за время жизни одного поколения машин. Каждый новый жизненный цикл производственных инноваций нуждается в радикальных изменениях характера подготовки квалифицированных кадров, особенно в технических вузах, где готовится основная масса инженерных кадров. От их квалификации в огромной мере зависит продвижение страны по пути технического прогресса (Квасов, 2011).

Существенное влияние оказывает и историческое размещение центров высшего образования. В настоящее время основными центрами (по показателю численности студентов образовательных учреждений высшего образования в 2009-2010 годы) являлись: Москва (1231 чел.), Санкт-Петербург (988 чел.), Томская область (827 чел.). Для сравнения: Московская и Ленинградская области занимают по этому показателю только 75-е и 81-е места (Регионы России, 2010). Красноярский край занимает 43-е место при 435 студентов на 10000 человек населения.

В целом система образования недостаточно ориентирована на удовлетворение потребностей инновационного развития и экономики в целом.

4. Наличие личностных качеств (мобильность, желание обучаться в течение всей жизни, склонность к предпринимательству и принятию риска) для восприятия населением инноваций. Во многом это связано с уровнем жизни (по данным официальной статистики, в 2010 году безработица в России составила 9,2\%, численность бедных (граждан с денежными доходами ниже величины прожиточного минимума) - $15,0 \%$ от общей численности населения). Низкие доходы и такое же качество жизни значительной части населения России вынуждают россиян решать проблемы жизнеобеспечения и не способствуют инновационности.

Таким образом, решение негативных тенденций в данном направлении позволит повысить мобильность человеческого капитала.

Одним из существенных факторов, влияющих на инновационную восприимчивость, выступает финансово-кредитное и инвестиционное обеспечение инновационной деятельности. Проблема достаточности и доступности финансовых ресурсов наблюдается на всех уровнях иерархической структуры - от предприятия до государственного уровня.

В Проекте Стратегии инновационного развития Российской Федерации на период до 2020 года указывается, что неинновационный характер государства в первую очередь выражается в недостаточном объеме финансирования научной и инновационной сфер (ассигнования на гражданскую науку из средств федерального бюджета в 2009 году составили 0,56\% ВВП). За период с 2005 по 2009 год доля средств отечественного предпринимательского сектора во внутренних затратах на исследования и разработки уменьшилась с 30,0 до 26,6\% при увеличении доли средств государства с 61,9 до 66,5\%. В целом затраты на технологические инновации организаций промышленного производства составили в 2009 году 358,9 млрд руб. (0,9\% ВВП).

Расходы российских компаний на НИОКР (в процентах ВВП) значительно ниже, чем в странах - инновационных лидерах и странах «второго эшелона», и составляют 1,04\% в России по сравнению с 2,5-4,5\% в среднем в странах - инновационных лидерах и 1,5-2,5\% в странах «второго эшелона».

По данным Минэкономразвития, уровень внутренних затрат на исследования и разработки в расчете на одного исследователя в России в 2009 году составил 60,1 тыс. долл. США (по ППС), при отставании России от Китая в 1,3 раза, от Франции - в 3,3 раза, от США - в 4,4 раза (Инновационная Россия... ).

Возможность более активного использования финансовых ресурсов для реализации инновационной деятельности ограничивается вследствие влияния следующих обстоятельств:

1. Наличие источников финансирования. Анализ источников финансирования показывает, что преимущественно научные исследования как основополагающий элемент 
инновационной деятельности получают средства из бюджетов разных уровней. В последние годы значительно увеличено финансирование науки за счет средств государства - как в части фундаментальной науки (в 1,6 раза за период 2006-2008 годов), так и в части прикладных разработок, в том числе через механизм федеральных целевых программ, через государственные фонды финансирования науки. Часть государственного бюджета на исследования и разработки распределяется на конкурсной основе через три фонда: Российский фонд фундаментальных исследований; Российский гуманитарный научный фонд; Фонд содействия развитию малых форм предприятий в научно-технической сфере.

2. Собственные средства предприятий составляют незначительную долю в источниках, что обусловлено рядом как объективных (низкий уровень рентабельности, недостаток собственных оборотных средств и т.д.), так и субъективных (отсутствие мотивации к осуществлению инновационной деятельности и т.д.) факторов. В последнее время характерной чертой становится финансирование за счет собственных средств инновационной деятельности крупными транснациональными корпорациями и объединениями. Инструменты кредитного рынка выступают как наиболее востребованные.

3. Стоимость финансовых ресурсов. Инновационная экономика не может работать при 14,5\% по кредиту, максимальная ставка должна быть не более 3-4\% при неизменности их величины на протяжении 5-10 и более лет.

4. Период использования финансовых ресурсов. Специфика инновационной деятельности требует привлечения финансовых средств на достаточно длительный срок при наличии высокого риска. Кредитные организации не заинтересованы в предоставлении кредитов на таких условиях.

5. Наличие и многообразие инструментов финансирования. Полученные в результате анализа инновационного законодательства субъектов СФО данные свидетельствуют о достаточно широком перечне инструментов, доступных для финансирования инновационной деятельности, но при этом непосредственно в инновационном законодательстве регионов механизм их реализации рассматривается недостаточно четко и полно. Наблюдается дисбаланс в количестве используемых видов инструментов по регионам: например, лидером являются Иркутская и Новосибирская области, аутсайдерами - Красноярский край, Республика Алтай. Самыми распространенными формами, предусмотренными нормативноправовыми актами, на мезоуровне являются субсидии, налоговые льготы и предоставление госгарантий. В группу менее используемых входят субвенции, инвестиционный налоговый кредит, бюджетное кредитование, освобождение от арендной платы за пользование имуществом. Практически нигде не определяется возможность инвестирования через фонды венчурного капитала (кроме Алтайского края) и стимулирование спроса за счет размещения госзаказа (кроме Кемеровской области). Текстуальный анализ инновационного законодательства регионов Сибирского федерального округа (СФО) также показывает, что основным источником финансирования инновационной деятельности продолжает оставаться региональный бюджет. Предполагается достаточно широкое использование средств зарубежных инвесторов и внебюджетных средств.

В сопоставлении с общероссийской практикой субъекты СФО используют не всю доступную линейку. В целом по стране 73 субъекта федерации применяют налоговые льготы, 61 - гарантии по займам, 60 практикуют соинвестирование коммерческих проектов, 50 регионов предоставляют инвестиционные налоговые кредиты, 43 субсидируют процентные ставки (Национальная инновационная система...).

6. Наличие инновационных финансовых институтов, соответствующих рыночной экономике. В настоящее время создана современная система институтов развития в сфере инноваций, включающая институты предпосевного и посевного финансирования, венчурные фонды с государственным участием (через ОАО «Российская венчурная компания»), Банк развития и внешнеэкономической деятельности (Внешэкономбанк), Государственную корпорацию «Роснанотех», поддерживающую проекты в сфере нанотехнологий.

За период с 2005 по 2008 год в 21 регионе создано 23 региональных венчурных фонда. 
Практически все фонды ведут активную работу по отбору инвестиционных проектов и финансированию выбранных. По состоянию на 30 мая 2009 года общая капитализация региональных венчурных фондов составила 8,650 млрд рублей, из которых средствами федерального бюджета являются 2,1 млрд рублей, общее количество компаний, получивших инвестиции, - 29, а суммарный объём инвестиций равен 1,4 млрд рублей. При этом половина инвестиций фондов осуществлены в информационно-телекоммуникационные малые компании, пятая часть - в биологические и медицинские технологии и оборудование, каждый десятый проект - из индустрии наносистем и нанотехнологий. Около 45\% проинвестированных проектов находится на стадии разработки продукта, каждый пятый проект представлен компаниями, осуществляющими тестовые поставки продукта (Обзор рынка прямых...).

Обобщение вышеизложенного позволяет сделать следующий вывод: финансовое обеспечение инновационной деятельности не может базироваться на одном источнике государственном или частном, поскольку бюджетное финансирование не создает подлинной заинтересованности субъектов в окупаемости вложений, а частный капитал, особенно в российских условиях, не склонен к инвестициям с высоким технологическим, коммерческим и политическим риском, с длительным сроком окупаемости и жесткой зарубежной конкуренцией.

Важно отметить, что уровень конкуренции делает субъектов инновационной деятельности более требовательными к качеству институциональной среды. Инновационная деятельность требует обеспечения современной функционирующей институциональной системы, что в первую очередь связано с формированием инновационной инфраструктуры.

Исследования показывают, что к настоящему времени не сложилось единого понимания содержания понятия «инновационная инфраструктура». В «Основных направлениях политики Российской Федерации в области развития инновационной системы на период до 2010 года» инновационная инфраструктура определяется как совокупность объектов инновационной деятельности, способствующих осуществлению инновационной деятельности, включая предоставление услуг по созданию и реализации инновационной продукции (Основные направления...).

На современном этапе в России наблюдается фаза активного формирования инновационной инфраструктуры как на национальном, так и на региональном уровнях. Это выражается в количественных характеристиках и многообразии форм: в настоящее время в России зарегистрировано более 110 технопарков, еще больше - инновационнотехнологических центров, более 100 центров трансфера технологий, 10 национальных инновационно-аналитических центров, более 80 центров научно-технической информации, 129 бизнес-инкубаторов, 15 центров инновационного консалтинга и другие организации инновационной инфраструктуры. Национальный информационно-аналитический центр по мониторингу инновационной инфраструктуры научно-технической деятельности и региональных инновационных систем в настоящее время поддерживает информацию о 834 организациях инновационной инфраструктуры [www.sci-innov.ru].

Важной проблемой для уже созданных и действующих институтов инфраструктуры является низкая эффективность их деятельности. Многие процедуры, реализацию которых предусматривает данная организация, длительны в реализации, проходят всевозможные согласования и утверждения, во многом бюрократизированы, что приводит к устареванию технологических решений.

Обобщение опыта процессов формирования и функционирования инновационной инфраструктуры позволяет автором статьи выделить следующие проблемы:

- отсутствие теории инновационной инфраструктуры, в том числе концепции формирования и развития региональной инновационной инфраструктуры;

- доминирование федеральной зоны ответственности федеральных органов власти при создании институциональной среды, ориентированной на инновационное развитие;

- отсутствие четко обозначенной позиции региональных органов власти в части 
концептуального подхода к формированию инновационной инфраструктуры в регионе (во многих регионах);

- взаимодействие субъектов экономики преимущественно осуществляется приоритетно по неформальным правилам по отношению к формальным;

- разбалансированность существующих элементов инновационной инфраструктуры, связанная с преобладанием доли институтов организационной и технологической компонент;

- отсутствие системы мониторинга качественного состояния инфраструктуры, отражающей функциональный состав ее элементов;

- отсутствие или слабые связи между институтами инфраструктуры, что снижает эффективность их взаимодействия.

Значимым фактором формирования инновационной восприимчивости является нормативно-правовое обеспечение, регулирующее инновационную сферу. Отсутствие целостной системы федерального инновационного законодательства, охватывающей все аспекты и этапы инновационной деятельности, проецируется на региональный уровень, обосновывая его специфику. Вышеперечисленные условия и проблемы обосновывают необходимость выделения и определения инновационного законодательства в качестве особой, комплексной отрасли законодательства.

Существенным фактором является, по мнению авторов, взаимодействие общественных организаций и субъектов инновационной деятельности, которое должно рассматриваться с позиций реализации инициатив, выдвигаемых данными организациями. На данном этапе не в полной мере задействованы потенциалы Торгово-промышленной палаты, Союза промышленников и предпринимателей, Союза сельхозпроизводителей, Всероссийской общественной организации малого и среднего бизнеса и др.

Важным фактором является уровень инновационности органов управления. Аналитики отмечают недоверие российских разработчиков «инновационным» чиновникам. Всего 1,5\% опрошенных сказали, что государственные чиновники делают достаточно для развития инновационного сектора, $8 \%$ оценили эти усилия как средние, $37 \%$ - как минимальные, а $53 \%$ считают, что чиновники вообще ничего не делали для поддержки инноваций (Расков, 2010).

На наш взгляд, также необходимо особо выделить достаточно специфический фактор: воздействие системы хозяйствования. В регионах России последствия административнокомандной системы хозяйствования продолжают оказывать влияние на восприимчивость территории к инновациям и распространяются настолько, что определяют инновационный потенциал отдельных территорий в долгосрочном периоде.

Выявление и рассмотрение основных факторов, определяющих инновационную восприимчивость, позволило провести их классификацию с использованием структуры признаков, имеющих разные свойства (таблица 2).

Таблица 2

Классификация факторов инновационной восприимчивости

\begin{tabular}{|c|c|}
\hline Классификационная группа & $\begin{array}{c}\text { Дифференциация классификационной } \\
\text { группы }\end{array}$ \\
\hline $\begin{array}{l}\text { Сфера воздействия на инновационную } \\
\text { восприимчивость }\end{array}$ & $\begin{array}{l}\text { - внешние } \\
\text { - внутренние }\end{array}$ \\
\hline \begin{tabular}{lcc} 
Характер & \multicolumn{1}{c}{ воздействия } & на \\
инновационную восприимчивость & \\
\end{tabular} & $\begin{array}{l}\text { - способствующие развитию (стимулирующие) } \\
\text { - ограничивающие развитие (тормозящие) }\end{array}$ \\
\hline $\begin{array}{l}\text { Инновационная восприимчивость } \\
\text { элементов инновационной деятельности }\end{array}$ & $\begin{array}{l}\text { - экономические } \\
\text { - технические и технологические } \\
\text { - организационные } \\
\text { - управленческие } \\
\text { - социальные }\end{array}$ \\
\hline
\end{tabular}


Измерение инновационной восприимчивости и ее повышение обуславливают выявление внешних и внутренних факторов влияния. Экзогенными выступают: возросшая конкуренция, нестабильность внешней среды как основное проявление временного фактора; инновационный климат (состояние финансовой, налоговой, правовой, научнопроизводственной поддержки инновационной активности со стороны федеральных, региональных и муниципальных властей системного и отраслевого характера; инвестиционный климат; инновационная конкурентная среда. Эндогенные: открытость региональной социально-экономической системы; компетентность ее руководства и специалистов; стратегическая гибкость; мотивация специалистов и руководства.

По характеру воздействия на инновационную восприимчивость целесообразно выделение группы стимулирующих и тормозящих факторов. Стимулирующими факторами является обеспечение институциональной поддержки, создание и развитие региональных инновационных систем, система подготовки кадров для инновационного сектора, формирование инновационной инфраструктуры и др. Факторами, не способствующими инновационной восприимчивости, выступают антиинновационное поведение руководителей субъектов, отсутствие инициативы.

Определение факторов инновационной восприимчивости, связанных с отдельными элементами производственного процесса, выделяет группу экономических (обеспечивающих формирование благоприятных экономических условий для инновационной деятельности государственное финансирование, инвестиционная активность, кредитная, налоговая политика, финансовые ресурсы и инструменты и др.), технических (состояние основных фондов, наличие современных технологий и т.д.), организационных (регламентирующих процедуры, связанных с развитием и функционированием инновационной активности), управленческие (формирующие процессы управления - управленческие технологии, методы управления и др.), социальные (направленные на создание благоприятных условий для деятельности инновационных структур - мотивация субъектов, развитие инновационной культуры и др.).

В целом проведенная в ходе исследования систематизация воздействия факторов на уровни субъектов позволило выявить приоритетные специфические условия формирования инновационной восприимчивости региона, к числу которых следует отнести эффективную координацию государственных действий в сфере инноваций, наличие в регионе инновационной инфраструктуры и инновационной региональной нормативно-правовой базы.

Одновременно с этим подчеркнем важность понимания того, что все факторы находятся в тесном взаимодействии и меняют свои качества по мере развития инновационных процессов. При этом следует помнить, что недооценка факторов, определяющих инновационную восприимчивость региона, влечет за собой отсутствие эффекта от инноваций, проявляющегося в инерционности хозяйствующих субъектов, диспропорциях наличия и реализуемости инновационных возможностей на практике, миграции инновационных технологий.

\section{Список литературы}

1. Беляев М. Механизм управления факторами развития современных экономических систем // Проблемы теории и практики управления. 2006. № 11. С. 19-24.

2. Владимирова О.Н. Организационно-экономические и институциональные основы формирования и функционирования региональных инновационных систем: монография. - М.: Доброе слово, 2011.

3. Гончар К. Инновационное поведение промышленности: разрабатывать нельзя заимствовать // Вопросы экономики. 2009. № 12. С. 125-141.

4. Инновационная Россия - 2020. Стратегия инновационного развития Российской Федерации на период до 2020 года: проект Минэкономразвития. URL: 
http://www.economy.gov.ru/minec/activity/sections/innovations/doc20101231_016.

5. Квасов И.Н., Пивоварова А.В. Анализ инновационного потенциала региона // Финансовая аналитика: проблемы и решения. 2011. № 1 (43). С. 26-31.

6. Митяшин В.Г. Методологические и прикладные вопросы технологического аудита российских промышленных предприятий // Инновации. 2010. № 4. С. 59-68.

7. Национальная инновационная система и государственная инновационная политика РФ: Базовый доклад к обзору ОЭСР национальной инновационной системы Российской Федерации. URL: http://www.mon.gov.ru/press/news/6333.

8. НАИРИТ составила рейтинг инновационной активности регионов 2009 г. URL: http://www.nair-it.ru/news/10.03.2010/135.

9. Обзор рынка прямых и венчурных инвестиций за 2008 год. - СПб.: Феникс, 2009.

10. Расков Н. Долговременные тенденции развития экономики // Экономист. 2010. № 5. C. 27-40.

11. Регионы России. Социально-экономические показатели. 2009: стат.сб./ Росстат. - М., 2010.

12. Российские «мозги» снова хлынули за рубеж. URL: http:// www.infox.ru/business/company/2010/03/19/_Utyechka_mozgov__print.phtml.

13. Основные направления политики РФ в области развития инновационной системы на период до 2010 года. URL: www.donland.ru/Default.aspx?pageid=88668.

14. Рубанов И. Отодвинем старость подальше // Эксперт. 2009. № 42. С. 19-26.

15. Федеральный портал по научной и инновационной деятельности. www.sci-innov.ru.

16. Acemoglu D., Aghion Ph., Zilibotti F. Distance to Frontier, Selection, and Economic Growth // Journal of the European Economic Association 4. 2006. № 1. P. 37-74.

17. Acemoglu D., Aghion Ph., Lelarge C., Reenen J.Van and Zilibotti F. Technology, Information, and the Decentralization of the Firm // Quarterly Journal of Economics 122. 2007. № 4. P. 1759-1799. 